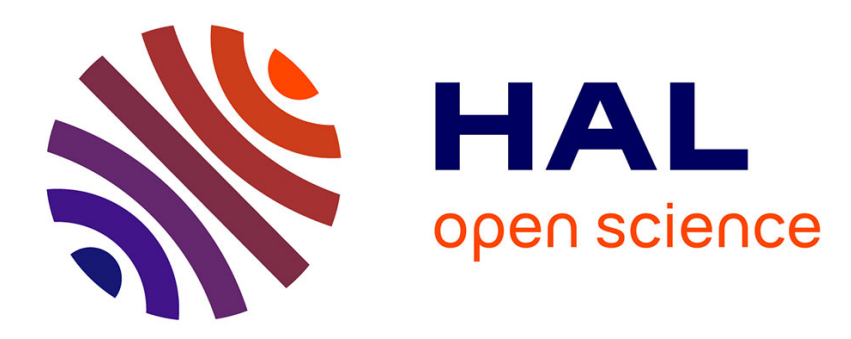

\title{
The inadequacy of french rural school public policies
}

\author{
Yves Alpe, Angela Barthes
}

\section{To cite this version:}

Yves Alpe, Angela Barthes. The inadequacy of french rural school public policies. Evolutions of the Complex Relationship Between Education and Territories, Wiley. Hoboken. New Jersey, 2018. hal-01763380

\section{HAL Id: hal-01763380 \\ https://hal.science/hal-01763380}

Submitted on 11 Apr 2018

HAL is a multi-disciplinary open access archive for the deposit and dissemination of scientific research documents, whether they are published or not. The documents may come from teaching and research institutions in France or abroad, or from public or private research centers.
L'archive ouverte pluridisciplinaire HAL, est destinée au dépôt et à la diffusion de documents scientifiques de niveau recherche, publiés ou non, émanant des établissements d'enseignement et de recherche français ou étrangers, des laboratoires publics ou privés. 


\section{The inadequacy of French rural school public policies}

\subsection{Summary}

The findings of research works carried out in the 1970s revealed a "lack" of performance by rural students. Those of the years 1990-2000 show a reversal of trend, with academic success rather better than that of urban students. This fact constitutes "the paradox of the rural school's good results" (better results and disadvantaged social backgrounds), but it is coupled with a lack of ambition among rural students and a lower social position in the end. Research performed in the 2010s shows that these rural areas' specificities (lack of ambition and obstacles to mobility) tend to decrease today. But we also posit that the rural students' good results are today undermined by the inadequacy of public policies with regard to rural territories' needs, which reduce rural students' success factors nonetheless identified by researchers.

\subsection{Introduction}

The so-called "rural" school has been a problematic subject for nearly a century, for those responsible for educational policies and for researchers in sociology or education science. This is due to three main factors. The first is the significance of the rural area in French society. It explains the importance of debates on the rural in opinion in general as well as in the political sphere, particularly because rural territories are overrepresented in central political bodies, such as the Senate. The second refers to the very great sensitivity that has developed in our society regarding issues relating to the inequality of educational opportunities connected with the

Chapter written by Yves ALPE and Angela BARTHES. 
popularity of theses on the "sociology of reproduction" (Bourdieu \& Passeron, 1970). The third factor is the societal dimension of the rural school, which is seen as a social reality to be protected, an indispensable support for village life as well as a balancing factor for the maintenance of fragile hinterlands in the national equilibrium of territory development. As a result, the rural school has been a major concern for so-called "territorialized" educational policies, since the social discourse has moved towards downgrading it. These policies have not always led to the consideration of the realities of rural issues, but on the contrary have contributed to the stigmatization of these schools and their territory, with serious consequences for rural students.

The purpose of this article is to recall how this stigmatization was constituted, how it was discussed, especially by research, and how the debate is presented today, in view of the changes affecting rural areas, and their inhabitants. We will endeavor to show that socio-educational strategies have evolved and they raise the issue of the adequacy of public education policies to the social reality of present day rural life. The article will mainly base on a set of works carried out between 1999 and 2012 (7 surveys) by the Education and Territories Observatory (see Box 14.1).

\subsection{Rural school contexts and recent research developments}

\subsubsection{Age-old delay of the rural school and its poor image}

The history of school shows the slow diffusion of education in rural areas, with an age-old delay of the countryside over the city. In effect, initially, following the Order of 1698 "small schools" first flourished but remained confined to the most economically favorable areas, that is, mainly the cities. School gradually expanded into the countryside much later, following the French Guizot 1833 (municipalities with more than 500 inhabitants are required to have a boy's school) and Falloux 1850 (establishing the principle of a boy's school in all municipalities and a girls' school for "those who have the means," and Ferry 1881-1882 (marking the real beginning of the penetration of schools in small rural municipalities) laws. However, during this period school attendance in the countryside remained irregular and depended on agricultural calendars. There was thus an almost four generations gap between the countryside and the cities, which for a long time refused to provide the modern city image to a remote countryside which was poor and populated by undereducated peasants, and this was still anchored in memories. To this picture could be added a century of rural exodus (which accelerated after 1945), which for a long time tarnished the image of the countryside as being repulsive and a territory full of backwardness. This image extended to the school itself, and after the 1960s, its image gradually became that of a 
"bad school" accused of not offering its students the same opportunities as the urban school.

In the 1960s, added to this, was the first major postwar survey (INED, 1962; Girard, Bastide and Pourcher, 1963) dealing with an essential issue at the time: the rate of access to Sixième (sixth grade or form one) according to the area of habitation of CM2 (grade five or class six) students. This very detailed work examined many factors (students' gender and age, social background, etc.) and addressed the "geographical factor" (p.70). Only $42 \%$ of students from the "countryside" entered Sixième, $28 \%$ of whom were in general secondary school and $14 \%$ in high school, while $72 \%$ of those in Paris urban area had access to this class, $39 \%$ in general secondary school and 33\% in high school. The authors emphasized the importance of two factors: the social origin and geographical location of secondary and high schools (page 72).

Henceforth, many research works (those carried out within the framework of the IREDU for example) attempted to analyze the causes of this difference in schooling. In addition to the issue of the sociological composition of rural students' families, most of this work focused on the role of the school structure, addressing in particular one of the main characteristics of the rural school: the existence of many single classroom or multigrade classes schools. They tended to discredit small schools and single classroom schools (1980s), and emphasized on the "cultural deficit" of students in these schools, and their "poor" academic performance.

\subsubsection{The reversal of trends from the 1990s: towards the observation of good academic performance of rural students}

However, successive studies gradually showed a reversal of trends, which will cast doubt on the presumed rural students' deficit. The Ministry sponsored new studies, which appeared in the form of a special issue of the journal Éducation \& formations («Le système éducatif en milieu rural »(Education \& Training ("Education System in the Rural Area")) No. 43, Oct. 1995). This very significant work took the opposite view of many affirmations of previous years. Analyses by F. Oeuvrard (2003, p. 159) shows that rural schools had better scores on national assessments in French (65.3\% against 64\%) and mathematics (69\% against 66.3\%) than urban schools. She also points out (page 160, op.cit.) the positive effects of multiple lessons classes, and better results for rural workers' children. Subsequently, surveys of the Education and Territories Observatory on rural students from six French rural departments (Ain, Alpes-de-Haute-Provence, Ardèche, Drôme, Haute Loire, Haute Saône) confirmed these data (Alpe, Champollion \& Poirey, 2003); moreover, the 
proportion of delayed students in CM2 in 1999 was lower than the national average (18\% against $19 \%)$.

Thus, in the late 1990s, it was established by researchers that rural areas have good academic results. This was reflected by a rather better performance of rural students, especially if we take into account their generally underprivileged social background, what we call "the paradox of the rural school." Indeed, the rural areas are mostly made up of families of humble social background and yet, the academic performance of students in these areas is higher than those of students from urban areas. At the same time, however, it is also shown that rural students have a lack of ambition, which implies an ultimately less valued social position. Even with equal results, more rural than urban students move towards short term vocational education at the end of Troisième (final year lower secondary school or form four), and consider shorter studies after the Baccalaureate (Alpe \& Fauguet, 2008). This tendency is further enhanced by enrolment in single classroom schools (Féraud, 2003). In relation to these characteristics updated by the research works of the 1990s and during the $2000 \mathrm{~s}$, researchers argue that there is a rural and, above all, mountain areas specificity in terms of schooling and even talk (sometimes relatively non systematically - the rural, which is not identical everywhere, is not the mountain! for some of them?) of "territory effects."

\subsubsection{What recent studies on the rural school apparently reveal: the end of rural students specificity?}

Since 2010, new research has emerged, showing recent developments in rural schools (Barthes, Champollion, 2014, Alpe, Barthes \& Champollion 2016). These studies clearly pose the issue of the end of a rural specificity of school. This research questions the evolution of school itself, and also that of public policies implemented and their adequacy with the current educational realities of the countryside.

\subsubsection{Longitudinal surveys - corpus and methods}

At the beginning of the 1990s, the creation of IUFMs (university teacher training institutes) modified the context of educational research, and brought to light new questions: above all, it aims to provide (beyond the didactic and pedagogical concerns) a scientific basis to the teacher training content, particularly in the social sciences. In 1999, OER researchers (see Box 14.1) launched a series of investigations among rural students, which helped in providing new data on their educational trajectories and on territorial education inequalities. 
This research structure which was created in 1997 by researchers and trainers from five IUFMs (Aix-Marseille, Auvergne, Grenoble, Lyon, Franche-Comté), launched from 1999 a series of surveys of rural students (and their parents), from the follow up of a cohort of 2,400 rural students from six departments (Ain, Alpes-de-Haute-Provence, Ardèche, Drôme, Haute Loire, Haute Saône). Students were interviewed four times in 1999 (CM2), 2002 (Cinquième), 2004 (Troisième) and 2005 (Seconde) and further surveys were conducted with urban students in 2004 (Troisième), and to locate the students of the cohort in 2007. The OER became OET (Education and Territories Observatory) in 2006, and continued its research work, with new surveys, from the follow up a cohort of 1,208 students monitored in 2012 (CM2), 2014 (Cinquième) and 2016 (Troisième), to which was added a one-off, nonsurvey monitoring of 959 Troisième students in 2012 among rural students in the Alpes-deHaute-Provence, Ardèche and Drôme). These new surveys took up the questionnaires of previous investigations, focusing on students' trajectories and, as far as possible, the same schooling places (primary and secondary schools). The OET developed partnerships with several research laboratories and universities (Universities of Aix-Marseille, Caen, Corsica, Franche-Comté, Barcelona, Lisbon, ...) and disseminated its results through open seminars (two per year since 1997) and many academic works (theses, etc.) including publications, the list of which could be found on its website (observatoire-education-territoires.com).

The first OER 1999-2005 database, which included 18,000 questionnaires (students and parents), focused on school trajectories, cultural practices, career orientation and study projects, opinions about the territory, primary and secondary schools, but also on the "opening policies" of primary and secondary schools as well as their effects.

\section{Box 14.1. From the Rural School Observatory (OER) to the Education and Territories Observatory (OET)}

These works thus made it possible to posit a certain number of hypotheses concerning the evolutions of rural students' characteristics. We present here very briefly some of the main characteristics of the two samples on which the comparative diachronic studies of the two longitudinal follow ups are based. First observation, there are little changes in the socioprofessional composition compared to the first surveys, which is not surprising given the relatively short period (12 years).

\begin{tabular}{|c|c|c|c|c|}
\cline { 2 - 5 } \multicolumn{1}{c|}{} & OSC1 & OSC2 & OSC3 & OSC4 \\
\hline CM2 1999 & 9 & 11 & 51 & 29 \\
\hline CM2 2011 & 14 & 10 & 39 & 37 \\
\hline
\end{tabular}


Table 14.1. Father's occupation and socioprofessional category (OSC)

(in \% of total responses), OET 1999 surveys (1,238 responses) and 2011 (592

responses)

These data also confirm the relative underprivileged social backgrounds in rural areas, since at the national level, at the start of the 2013 academic year, OSC $1+2$ represented $33.6 \%$ of students in public education (MENESR / DEPP), against $24 \%$ here.

\subsubsection{The end of self-stigmatization of rural students?}

Moreover, these data lead to the observation that opinions about schooling have changed, and students have slightly more positive opinions about their own academic level: urban data collected under the same conditions in 2015 (64\% of students rating themselves good or very good) show that the rural / urban difference evidenced by the 1990s studies has disappeared today.

\begin{tabular}{|c|c|c|c|}
\cline { 2 - 4 } & $\begin{array}{c}\mathbf{1 9 9 9} \\
\text { (rural } \\
\text { students) }\end{array}$ & $\begin{array}{c}\mathbf{2 0 1 1} \\
\text { (rural } \\
\text { students) }\end{array}$ & $\begin{array}{c}\mathbf{2 0 1 6} \\
\text { (urban } \\
\text { students) }\end{array}$ \\
\hline $\begin{array}{c}\text { Rating themselves good or very } \\
\text { good }\end{array}$ & $49.3 \%$ & $63.4 \%$ & $64 \%$ \\
\hline $\begin{array}{c}\text { Total respondents } \\
\text { Non-response }\end{array}$ & 2229 & 685 & 348 \\
\hline
\end{tabular}

Table 14.2. Students' opinions on their own academic level in \% of total responses, 1999 and 2011 OET CM2 surveys

Despite this, students continue to express some concern about their immediate future, more marked in 2011 than in 1999: $46.7 \%$ of students think they pursue with ease in 1999 , compared to $42.5 \%$ in 2011 . These data are close to those of urban students (42\% in 2016).

The entry into secondary school remains for these students a reason for concern, which is probably related to the constraints generated: remoteness of the place of residence, boarding for some, etc.... The same phenomenon is found for Troisième students in view of entry into Seconde and thus departure for the high school ... and the city: 


\begin{tabular}{|c|c|c|c|c|}
\hline \multirow{2}{*}{} & \multicolumn{2}{c|}{2004} & \multicolumn{2}{c|}{2012} \\
\cline { 2 - 5 } & Students & Parents & Students & Parents \\
\hline With ease & 52 & 65 & 40,5 & 55 \\
\hline With difficulties & 48 & 35 & 59,5 & 45 \\
\hline Non-response & 15 & 375 & 66 & 436 \\
\hline Total & 1365 & 1365 & 959 & 959 \\
\hline
\end{tabular}

Table 14.3. "Next year, I am sure to pursue...," 2004 and 2012 non-survey monitoring of Troisième students in \% of total responses

These data (presented very briefly here) allow us to address the central question: do rural students' specificities, subjects of many social discourses and institutional points of view in the 2000 s, still exist today? The answer to this question lies partly in school projects.

\subsubsection{Rural students' school projects are becoming less and less specific}

Surveys make it possible to address students' projects by several indicators: their parents' wishes, their career orientation and further education plans, the duration of studies they are considering, and their professional plans. All these elements combine to give a fairly precise idea of the evolution of their projects. The most dramatic change concerns long term study projects.

It is clear here (despite the significant number of non-responses in 2011) that the weakness of the social demand for education, described as characteristic of rural people by the Lebossé report (1998), is disproved by the facts. In 1999, 48\% of parents wanted their children to pursue higher education, and the percentage rose to $66 \%$ in 2011. This evolution is reflected in the students' opinion regarding their age of leaving full-time education: in 1999, 68\% thought they would stop their studies before the age of 22, the percentage dropped to $52 \%$ in 2012 . The answers of Troisième students go in the same direction. In their shorter term career orientation wishes, the general Baccalaureate is increasingly often chosen (46\% in 2004, 58\% in 2012). 


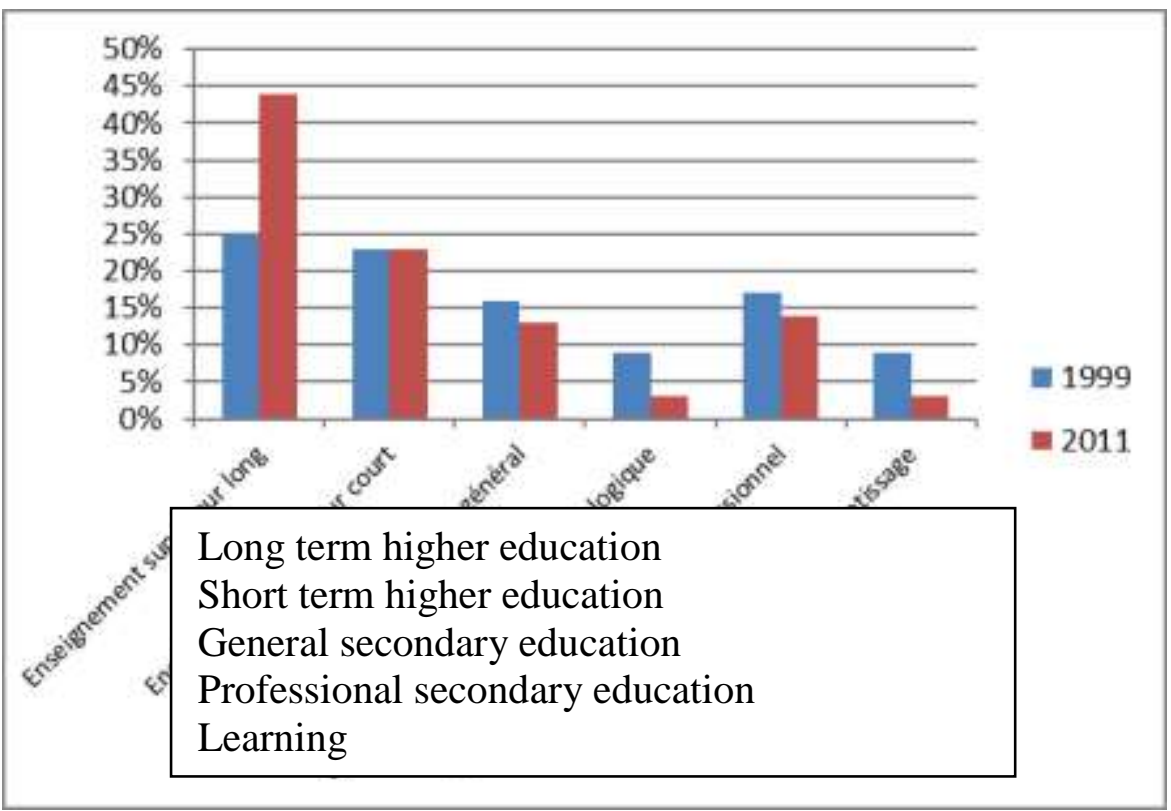

Figure 14.1. CM2 parents wishes, 1999 surveys (2,365 students, 234 non-responses), and 2011 (1,208 students, 508 non-responses)

\begin{tabular}{|c|c|c|c|c|}
\cline { 2 - 5 } & \multicolumn{2}{|c|}{ 2004 survey } & \multicolumn{2}{c|}{ 2012 survey } \\
\cline { 2 - 5 } & Number & $\begin{array}{c}\text { In \% of total } \\
\text { responses }\end{array}$ & Number & In \% of total responses \\
\hline Non-response & 60 & & 111 & \\
\hline General Bac & 472 & 46 & 493 & 58.1 \\
\hline $\begin{array}{c}\text { Technical Bac } \\
\text { Professional Bac }\end{array}$ & 131 & 12.8 & 78 & 9.2 \\
\hline $\begin{array}{c}\text { CAP-BEP, } \\
\text { learning }\end{array}$ & 244 & 17.4 & 229 & 27 \\
\hline $\begin{array}{c}\text { Number of } \\
\text { responses }\end{array}$ & 1,026 & 23.8 & 48 & 5.7 \\
\hline $\begin{array}{c}\text { Number of } \\
\text { students }\end{array}$ & 1,086 & & 848 & \\
\hline
\end{tabular}

Table 14.4. Troisième students' career orientation wishes, in \% of total responses, OET 2004 (follow up) and 2012 (one-off) surveys 
Plans to continue studies show the same trend.

\begin{tabular}{|c|c|c|}
\cline { 2 - 3 } \multicolumn{1}{c|}{ None* } & Troisième 2004 & Troisième 2012 \\
\hline Short term higher education & 66 & 20 \\
\hline Long term higher education & 14 & 34 \\
\hline \multirow{2}{*}{} & 20 & 46 \\
\cline { 2 - 3 } & 1,086 students, 23 NR & 959 students, 238 NR \\
\cline { 2 - 3 }
\end{tabular}

*BEP/CAP, stop after the Baccalaureate, etc.

Table 14.5. Plans of post Baccalaureate studies, in \% of total responses, OET 2004 and 2012 surveys

In 2012, $80 \%$ of them wished to pursue higher education: the percentage therefore more than doubled, rural students caught up with urban students.

\subsubsection{Rural students' professional plans are no longer significantly marked by their territory of residence}

The surveys make it possible to know students' professional plans, who were asked to express three wishes, in decreasing order of preference. Cohort follow up also shows the evolution of their plans between 1999 (CM2) and 2004 (current Troisième students). These projects depend primarily on two factors: the opinion they have of their academic level and social background. They are by contrast, not very marked by the rural nature of their place of residence.

The development of students' plans over time is quite weak. Dispersion in answers is slightly greater (17 occupations cumulate more than $50 \%$ of the answers in 1999 and 22 in 2004). Of the 17 in 1999, 14 are in the list of 2004. We find occupations traditionally chosen by students (depending on their age). The influence of the rural environment seems rather weak and decreasing: worth noting is the disappearance of the farming profession from the top of the list, and the decline of the profession of veterinarian (from 3rd to 18th position). If there is a "territory effect," it appears to be very diffuse and difficult to measure, given the complex interactions between many variables. But these surveys (Alpe, Champollion \& Poirey, 2006) also showed a certain modesty in future professional choices, 
correlated with equally moderate plans of higher education studies. We shall discuss this in the subsequent section.

\begin{tabular}{|c|c|c|}
\hline \multirow[t]{2}{*}{1999 survey } & \multicolumn{2}{|c|}{2004 survey } \\
\hline & & Position in 1999 \\
\hline teacher & teacher & 1 \\
\hline hairdresser & salesperson & \\
\hline veterinarian & childcare worker & 16 \\
\hline medical doctor & hairdresser & 2 \\
\hline farmer & nurse & 9 \\
\hline firefighter & computer scientist & 12 \\
\hline baker & engineer & \\
\hline police & esthetician & \\
\hline nurse & educator & \\
\hline mechanic & firefighter & 6 \\
\hline designer & baker & 7 \\
\hline computer scientist & sports teacher & \\
\hline cook & cook & 13 \\
\hline secretary & mechanic & 10 \\
\hline pharmacist & farmer & 5 \\
\hline childcare worker & electrician & \\
\hline \multirow[t]{6}{*}{ builder } & medical doctor & 4 \\
\hline & veterinarian & 3 \\
\hline & lawyer & \\
\hline & pastry cook & \\
\hline & secretary & 14 \\
\hline & builder & 17 \\
\hline
\end{tabular}

In yellow, trades common to both lists

Table 14.6. Desired occupations (1st wish) representing more than $50 \%$ of cumulative responses, ranked in descending order - 1,365 rural students interviewed in 1999 and 2004 
As a result of the changes mentioned above, we would have expected to observe major changes in the 2011 and 2012 surveys. This is not quite the case. In CM2, the answers are very close: 19 trades account for more than $50 \%$ of the responses in both surveys (50.6 in 1999 and 50.1 in 2011) and of these 19 trades, 13 are common to both lists ${ }^{1}$. We can also note the disappearance of the farming profession in the trades most cited in 2011.

\begin{tabular}{|c|c|c|}
\hline $\mathbf{1 9 9 9}$ & $\mathbf{2 0 1 1}$ & Position in 1999 \\
\hline teacher & veterinarian & 3 \\
\hline hairdresser & cook & \\
\hline veterinarian & footballer & 7 \\
\hline firefighter & teacher & 1 \\
\hline medical doctor & hairdresser & 2 \\
\hline farmer & police & 10 \\
\hline footballer & designer & \\
\hline baker & firefighter & 4 \\
\hline nurse & childcare assistant & \\
\hline police & singer & 12 \\
\hline designer & archeologist & 18 \\
\hline singer & medical doctor & 5 \\
\hline mechanic & actor & \\
\hline builder & esthetician & \\
\hline computer scientist & military & \\
\hline pharmacist & designer & 11 \\
\hline childcare worker & pharmacist & 16 \\
\hline archeologist & baker & 8 \\
\hline secretary & mechanic & 13 \\
\hline & & \\
\hline & & \\
\hline
\end{tabular}

Table 14.7. Occupations accounting for more than $50 \%$ of cumulative responses, ranked in decreasing order, OET, CM2, 1999 and 2011 surveys

For Troisième students (Table 14.8), the evolution of the lists is particularly interesting to observe. 21 trades accounted for more than 50\% of responses in 2004, and 23 in 2012. On these two lists, 16 trades are common. Just as for CM2 students,

1. In these surveys, all trade names are in the masculine form for reasons of statistical processing. 
the farmer occupation disappeared from the top of the list. But the variation in position of the common trades shows that it is the favored occupations (doctor, lawyer, etc.) that are moving up the rankings (see column 5). This category is also enriched by three occurrences $(*)$.

\begin{tabular}{|c|c|c|c|c|}
\hline 2004 & Position & 2012 & Position in 2004 & Var 1999/2012 \\
\hline teacher & 1 & salesperson & 2 & 1 \\
\hline salesperson & 2 & engineer & 8 & 6 \\
\hline childcare worker & 3 & architect & & * \\
\hline baker & 4 & cook & 14 & \\
\hline hairdresser & 5 & childcare worker & 3 & -1 \\
\hline nurse & 6 & hairdresser & 6 & -1 \\
\hline computer scientist & 7 & scientist, researcher & 12 & 5 \\
\hline engineer & 8 & baker & 4 & -4 \\
\hline esthetician & 9 & medical doctor & 18 & 9 \\
\hline educator & 10 & mechanic & 15 & 5 \\
\hline firefighter & 11 & teacher & 1 & -10 \\
\hline scientist, researcher & 12 & veterinarian & 19 & 7 \\
\hline sports teacher & 13 & lawyer & 20 & 7 \\
\hline cook & 14 & nurse & 6 & -8 \\
\hline mechanic & 15 & childcare assistant & & \\
\hline farmer & 16 & educator & 10 & -6 \\
\hline electrician & 17 & computer scientist & 7 & -10 \\
\hline medical doctor & 18 & journalist & & * \\
\hline veterinarian & 19 & electrician & 17 & -2 \\
\hline lawyer & 20 & gendarme & & \\
\hline \multirow[t]{3}{*}{ secretary } & 21 & physiotherapist & & \\
\hline & & military & & \\
\hline & & psychologist & & * \\
\hline
\end{tabular}

Table 14.8. Occupations accounting for more than $50 \%$ of cumulative responses, ranked in decreasing order, OET, Troisième 2004 (follow up) and 2012 (one-off) surveys

The only exceptions are the teaching and computer scientist professions, which both move down the rankings by ten positions. But overall, it is clear that here too rural 
students" "lack of ambition" seems to disappear (to be confirmed by the second OET follow up). In parallel, the 2015 results for urban schools show similar results (ongoing surveys carried out by the OET).

\subsubsection{End of rural students' attachment to their territory?}

It was therefore logical to question the relationship with the territory and its consequences. From this point of view, the OER surveys, which have the particularity of following students from CM2 to Troisième (and partially beyond, see box 14.1), provide elements not previously taken into account.

The outstanding fact in 1999 is the attachment of CM2 students to rural areas. This is manifested in their plans, since most of them would like to work later "in the countryside." This attachment gradually disappears, as shown by the answers of the same students 5 years later (students currently in Troisième): only $28.2 \%$ (against $39.9 \%$ in CM2) of them find the countryside attractive, and it is the small towns and medium cities which are appealing them. At the same time, attachment to the region of residence decreases, while the percentage of students considering working abroad has doubled: refraining from mobility sharply decreases with age.

The comparison between 1999-2011 and 2004-2012 reveals important changes. The first major change concerns the "desired locations" to practice their future occupation: the countryside's attraction has significantly decreased: for CM2 students, the percentage of those who want to work in the countryside has changed little, but those who want to work in a big city has moved from $34.1 \%$ to $49.8 \%$. The evolution is even more dramatic for Troisième students, who "would not like to work in the countryside" (46.8\% in 2012 against $24.8 \%$ in 2004 , out of 743 responses) and who prefer the city (54.8\% against $22.2 \%$, out of 817 responses). The "balance of opinion" regarding the future work location (see Table 14.9) has become very clearly unfavorable to the countryside.

\begin{tabular}{|c|c|c|c|c|}
\hline \multirow{2}{*}{} & $\mathbf{1 9 9 9}$ & $\mathbf{2 0 1 1}$ & $\mathbf{2 0 0 4}$ & $\mathbf{2 0 1 2}$ \\
\cline { 2 - 5 } & \multicolumn{2}{c|}{ CM2 students } & \multicolumn{2}{c|}{ Troisième students } \\
\hline Countryside & 10.7 & 1.6 & -2.4 & -21 \\
\hline Small town & 7.7 & 5.7 & 39.8 & 20 \\
\hline Big city & -21.8 & 13.7 & -6.7 & 32 \\
\hline \multicolumn{4}{|c|}{} \\
\hline Current region & 42.5 & 34.0 & 27.3 & 2 \\
\hline Other region(s) & -5.6 & -9.8 & 8.7 & 7 \\
\hline Other country(ies) & -41.9 & -29.2 & -3.0 & -1 \\
\hline
\end{tabular}


Table 14.9. Balance of opinion: \% of positive opinions

("I would like to work there") minus\% of negative opinions

("I would not like"), 1999, 2004, 2011 and 2012 OET surveys

This phenomenon is further enhanced by social background: in 2012, OSC1 students are the most favorable to "big cities" and the most unfavorable to the countryside (balance: -40.6 ).

Unsurprisingly, students wishing to work in the countryside are characterized by their strong reticence when it comes to mobility (going to work in another region or country). But the OSC effect is sensitive, and undoubtedly interferes with the representation of the territory: disadvantaged OSC experienced the highest mobility (measured by the rate of parents' relocation) in the years preceding the survey (OSC1: 17.6\% against OSC4: $30.7 \%$ ).

As expected, students wishing to work later in the countryside are those who value their current place of residence (at the time of the survey), which is, as a reminder, located in the rural area.

\begin{tabular}{|c|c|c|c|}
\hline \multicolumn{1}{c|}{ Many } & Average & Little or not at all \\
\hline I would like & 76.4 & 17.6 & 6 \\
\hline It doesn't matter & 53.8 & 37.5 & 8.6 \\
\hline I would not like & 31.8 & 42.6 & 25.6 \\
\hline
\end{tabular}

Table 14.10. Cross-tabulated: "Working in the countryside / appreciation of the place of residence," Troisième 2012 OET survey

\subsection{End of rural students "specificity" and inadequacy of public education policies}

\subsubsection{What the General Inspectorate's reports said about rural schools}

The academic establishment quickly gained awareness, with the issues of schooling in rural areas, in view of a sensitive issue hence the multiplication of the General Inspectorate of National Education's reports on this subject. If we hold onto the main ones, three major reports mark the variation of perspectives.

The first, the Mauger Report (1992), is based on a very alarmist observation regarding the situation of the rural education system in connection with demographic 
decline: it is characterized according to this report by isolation, small size of the units and difficulty adapting to innovations, especially as regards ICTE. It insists especially on the necessity of grouping the smallest structures: schools should have at least three classrooms, through the creation of intercommunal pedagogic groups as well as the abolition of single classroom schools, and secondary schools should have at least 300 students to avoid the disadvantages related to small size. This bias has raised many criticisms, encouraged the emergence of associations for the defense of rural schools, and strongly mobilized rural elected authorities against it. The arguments on which it was based were largely contradicted by subsequent research (including those sponsored by the Ministry itself in 1992), and the demographic prognosis, in many territories, contrasted sharply with "reruralization" action.

Two reports were published in 1998: the Ferrier Report, essentially devoted to pedagogic networks and "rural education networks," and the Lebossé report, entitled: «Pour une nouvelle dynamique du système éducatif en zone rurale isolée ». (Towards a New Dynamic of the Education System in Isolated Rural Areas). With the Duhamel Report (2003), these concern the most in-depth analyses conducted on the subject. This report recognizes the existence of satisfactory academic results in small rural schools, with reticence for those with the smallest enrollment. It carries out a critical analysis of the policy advocated since the Mauger Report and explicitly introduces the idea of "positive discrimination" (the expression is quoted as a paragraph) for the rural school. The report points to the least ambition of rural students, linked to the "sociocultural dimension of the rural area," and "weaker social demand for education," the root causes of geographical and cultural isolation ... This simplistic vision, which is not based on any serious study, leads to the valuation of groups policy already undertaken, and creates an "ideological attractor" (within the meaning of B. Charlot, 1997), the "sociocultural impediment" of rural students, which will remain strongly alive to present day.

The Duhamel Report partly takes up the conclusions of the Lebossé Report, but marks a break, in that it repeatedly takes a certain critical distance as regards the policies advocated: "Although all those who establish and coordinate groups agree on promoting the advantages rather than disadvantages, there is no serious demonstration or valid study showing that academic success is better in one case than in another. This is in line with the findings on the respective merits of single classrooms and other classes" (p. 76). And yet, a few pages further on (page 85), in its recommendations, the Report advises to "define or redefine school within the precise meaning of the term: as, for example, the mandatory minimum service guaranteed at least three classes covering the levels ...." 
Other reports will follow, but for the institution, the diagnosis is established: it is necessary to group small structures (despite the doubts mentioned above), and compensate cultural impediments related to isolation by innovative measures...

\subsubsection{Territorialized educational policies in view of rural developments}

Based on a diagnosis (questionable, as we have seen) of the mediocrity of rural school results, a method of dealing with this inequality of territorialized opportunities was gradually established in the 1980s and 1990s: the watchword becomes "grouping, compensating, adapting." Grouping is striving towards the elimination of single classroom schools; compensating is fighting against isolation through innovations such as EMALA ${ }^{2}$ or the development of ICTEs; adapting, are (rare) attempts to take into account the needs of the territory to adapt training (training for mountain area trades for example) ... This policy was at the time actively (and financially) supported by the $\mathrm{DATAR}^{3}$, in particular for the mountain region through "Massif schemes" of the 1980s.

All this works on two assumptions: that of the harms of isolation, and that of the "cultural deficit" of rural people, which leads to the relative lack of academic and professional ambition. However, what is shown by the works mentioned above suggests that rural students' "specificity," if it ever existed, gradually disappeared over the last twenty years until it became obsolete in the 2010s. This is not surprising in view of the sociocultural changes that occurred, particularly in the field of communications and networks, and socio-demographic transformations of increasingly heterogeneous rural populations. Furthermore, education policies indications concerning the rural school strive to eliminate multigrade classes, but conversely, all research work carried out show that it is precisely such policies that tend to increase good results, whatever the place (rural or urban) where this structure is operating.

This double observation leads us to posit that so-called "territorialized" educational policies are no longer adapted to realities on the ground. The issue of the inadequacy of educational policies is not new (Charlot 1994, Derouet 2000), but in the context of a global policy reform proposed by "Act III" of decentralization (Rey, 2013) and recomposition of territories, they obviously have a crucial importance, which goes far beyond the institutional context.

The inadequacy of public education policies results from several factors. They are based on a centralized administrative model, which considers the local level as a

2. Academic Mobile Liaison and Coordination Teams

3. Delegation for Territorial Development and Regional Action. 
special case to be included in a global standard; as a result, they can only ignore the objectives and strategies of local actors, with whom they often come into conflict (see the clashes over the former "school map").

Moreover, like many public policies (health policies for example...) they are justified by efficiency models (the "student cost" for example) which testify above all the significance of budgetary and accounting concerns: in education, they are also found when the priority education zones (ZEPs) are replaced by new policies known as "equal opportunities" or by the "Cordées de la réussite" (roped together for success) for example (Alligier, Cornand \& Alpe, 2013). These policies are totally "deterritorialized," since the treatment of inequalities is based on the unexploited individual "potential" of selected students. And in the field under discussion, they have shown their inability (or refusal?) to take into account the evolution of the rural environment (see the discourses on the weak demand for education mentioned above) and more generally the contributions of research, while it finances part of it...

As a result, the territories (and especially the most fragile) face a double difficulty. They are themselves "disorganized" (as evidenced by the multiple attempts to redefine or recompose them) because the complexity of their historical construction leads them to respond more and more poorly to the needs of increasingly heterogeneous populations; and in view of this disorganization, territorialized policies often result in a reinforcement of the management of territories, whereas the inhabitants' demand is going in the opposite direction: innovation, at least in its initial phase, is only possible by giving territories greater independence. There is therefore a reinforcement of disorganization, whereof can be found consequences on the territory's representations and its potentialities (among students inter alia) and thus on educational trajectories. Moreover, this disorganization is all the more difficult to correct because it is based on a paradox.

Indeed, for education in rural areas, educational policies were based on the assumption of a rural students' "specificity" (linked to the constraints of the geographical and sociocultural environment), which explained the "lack" of results, ambitions, etc. If it turns out that this specificity is in the process of disappearing, we could, being very optimistic, consider that this is partly due to the effectiveness (still strongly contested by local actors) of these policies. The logical consequence should be their elimination, since the main argument that justified them has disappeared!

\subsection{Conclusion}

Recent developments in research related to rural school show that on the one hand, academic performance generally remains higher than that of urban students, taking into account the sociocultural background of students. But this is more due to 
the organization of multigrade classes and their effects on the medium term (positive effects which unfortunately gradually disappear in secondary school) than the characteristics of the territory itself, as previous research has led us to believe. There is no real (except very localized contexts as seen in the mountain area) visible and perennial territory effects, but structural characteristics such as small numbers, multigrade classes, the use of ICTE, local policies of openness to partnerships outside the school that are able to partially offset the effects of students' disadvantaged social backgrounds. Whereas, the complex interplay of these factors has never been thoroughly analyzed, as already acknowledged by the Duhamel Report cited above, and the opportunity to highlight strategies for academic success which remain the property of local actors, without genuine recognition, and therefore without any real possibility of evaluation. It is also observed that the training elements for school teachers (for single classroom schools and multigrade classes), which were quite common in the IUFMs of the 1990s, have often been reduced to the smallest dimension, because of successive "priorities" in institutional injunctions.

Given these findings, we can only note that the responses of public policies towards rural schools (and territorialized policies in general) rather contradict the realities on the ground formalized by the results of education science research. The grouping of classes for example, are justified with regard to policy by references to cultural deficits in rural areas and the lack of performance of rural schools, while the performance of rural students lies precisely in multigrade classes, for example. It also illustrates the difficulty of applying research results, even when funded by the school itself, from public action orientations. From this point of view, research on the rural school (Alpe, Barthes \& Champollion, 2016), as a special case of school / territory relationship, is a very dynamic field, where multidisciplinary inputs are essential, and could provide new elements of reflection on the conditions of academic success.

\subsection{Bibliographic references}

Alligier, N., Cornand, R. \& Alpe, Y., « Les bénéficiaires des dispositifs de discrimination positive scolaire : les "passerelles secondaire supérieur" », Actes du colloque Les politiques de lutte contre les inégalités et les exclusions éducatives en Europe - de la compensation à l'inclusion, disponible à l'adresse : http://centre-alain-savary.ens-lyon.fr/CAS/documents/archives/ manifestations, 2013.

Alpe, Y., Barthes, A. \& Champollion, P., École rurale et réussite scolaire, Canopé, Chasseneuildu-Poitou, 2016.

Alpe, Y., Champollion, P. \& Poirey, J-L. (DIR.), L'enseignement scolaire en milieu rural et montagnard, tome 4 : le devenir des élèves en fin de collège, parcours et projets, Presses Universitaires Franc-Comtoises, Besançon, 2006.

Alpe, Y. \& Poirey, J.-L. (DIR.), L'enseignement scolaire en milieu rural et montagnard, tome 2: au seuil du collège, Presses Universitaires Franc-Comtoises, Besançon, 2003. 
Barthes, A. et Champollion, P. (DIR.), L'école rurale et montagnarde en contexte méditerranéen : Approches socio-spatiales, vol. 6, Presses Universitaires de Franche-Comté, Besançon, 2014.

Bourdieu, P. \& Passeron, J.-C., La reproduction, Éditions de Minuit, Paris, 1970.

Charlot, B. (DIR.), L'école et le territoire : nouveax espaces, nouveaux enjeux, A. Colin, Paris, 1994.

Charlot, B., Du rapport au savoir - Éléments pour une théorie, Anthropos/Economica, Paris, 1997.

Derouet, J.-L. (DIR.), L'école dans plusieurs mondes, De Boeck Université/INRP, Paris, 2000.

Duhamel, M., Houchot, A., Cuby, J-F. \& Moulin, Y., L'évolution du réseau des écoles primaires, Rapport, disponible à l'adresse : http://www.ladocumentationfrancaise.fr/var/storage/rapportspublics/034000604.pdf, 2003.

Ferrier, J., Améliorer l'efficacité de l'école primaire, Rapport remis à Mme la ministre déléguée chargée de l'Enseignement scolaire, 1998.

Girard, A., Bastide, H. et Pourchier, G., « Enquête nationale sur l'entrée en sixième et la démocratisation de l'enseignement», dans Girard, A. (DIR.), "Population » et l'enseignement, Presses Universitaires de France, Paris, 1970.

Lebossé, J.-C., Pour une nouvelle dynamique du système éducatif en zone rurale isolée, Rapport, disponible à l'adresse: http://www.ladocumentationfrancaise.fr/rapports-publics/994001758pour-une-nouvelle-dynamique-du-systeme-educatif-en-zone-rurale-isolee, 1998.

Mauger, P. (DIR.), Agir ensemble pour l'École rurale, ministère de l'Éducation nationale et de la Culture, Direction de l'Information et de la Communication, Paris, 1992.

Oeuvrard, F., «Les performances de l'école rurale - Quelle mesure, dans quel objectif ? », dans « Le rural : terre d'exclusion? », Ville-École-Intégration Enjeux, n ${ }^{\circ} 134$, p. 151-164, 2003.

Rey, O., « Décentralisation et politiques éducatives », Dossier d'actualité veille et analyses, $\mathrm{n}^{\circ} 83$, p. 1, 2013. 



\section{Comparison of rural and urban area girls' career orientation at the end of Troisième}

\section{E3.1. Summary}

This research aims to study the territory's influence on rural area girls' career orientation. It was carried out within the framework of the broad longitudinal study of a rural cohort performed by the Rural School Observatory. The experimental method used thus made it possible to construct the observation via a questionnaire survey, and then to complete it, in particular, by the results of the Diplôme National du Brevet des collèges (National French Certificate of General Education). The data were collected from a total sample of 315 students, half rural, half urban, approximately. It was thus possible to make a comparison between two distinct groups: the first, from rural areas, and the second from the urban area. Though this research was able to confirm that girls more than boys opt for general and technological Seconde (tenth grade or form five) in general, it in particular highlighted above the expected overall result, that girls from rural areas orient themselves more significantly than girls from urban areas. The result obtained thus confirms that the observed territory effect on career orientation has a specific gender dimension.

\section{E3.2. Introduction}

The analysis of educational inequalities is a very rich field of research, which strongly developed in the second half of the twentieth century. The highlighting of the inequality of educational opportunities (Boudon, 1973; Bourdieu, Chamboredon \&

Chapter written by Boris MeUNIER. 
Passeron, 1970) was one of the major projects of the sociology of education in the 1960s and 1970s, which made it possible to identify a number of determinants of differences in educational trajectories and (academic and social) success. The key factor is, of course, that of social and cultural origin, but research has identified other causes, which are usually combined with social background, enhancing or mitigating its effects, depending on the case. In this chapter, from a thesis work, we will examine a particular case of this causal complexity: gender effects, widely studied (Baudelot \& Establet, 1992), and those of the territory (Barthes \& Champollion, 2014). More specifically, we will analyze the influence that a rural territory of schooling and residence can exercise on the educational trajectories of boys and girls (only the case of girls will be analyzed here).

\section{E3.3. Territory and gender}

The territory concept is undoubtedly important in the understanding of students' educational pathways, but it sometimes refers to stereotypes that some people convey, but also transmit, and that others integrate. For Yves Alpe and Jean-Luc Fauguet (2010), "we witness the development of a stigmatizing and sometimes staggered vision of the territory relative to the socio-geographic reality" (Alpe \& Fauguet, 2010, p. 156). This leads, they explain, to policy decisions sometimes in the opposite direction, preferring to base on representations rather than facts. This is what makes introducing the territory concept into the subject of this study significant. In attempting an approach to educational pathways via the territory variable, it is interesting to try to understand its influence on students' career orientation according to the urban or rural territory. Territory is a complex concept: "The difficulties are numerous when it comes to interpreting the territorial differentiations observed, these resulting from a complex combination of geographical, historical, economic, demographic and political factors" (Broccolichi, Ben-Ayed, Mathey Pierre \& Trancart, 2007, p. 31). This research is based on this definition of territory: "Territory is a geographical space giving rise to a sociological construction where the actors interact with it, either by consciously or unconsciously appropriating or rejecting it."

The social composition of rural areas has evolved considerably. However, we know that the "social category" factor strongly impacts on academic success and students' career orientation. Moreover, this social factor plays a role on parents and their choice of career orientation. Many studies show that girls have a higher level of education than boys at the national level, even in rural areas. But, as Jean-Jacques Arrighi (2004) has shown, a girl in an urban area has to enter the labor market with a higher level of education of about two additional years in order to have a job and salary equivalent to that of a boy in rural areas. 
Following the various works of the Rural School Observatory and from the analysis of figures of the Ministry of National Education, the problem retained is as follows: do girls from rural areas opt more for general and technological education because of the significance of the territory? For this study, the hypothesis is that girls from rural areas opt more for general and technological education than girls from urban areas; which would be due to their ambition for various reasons (distribution of training offer, fear of unemployment, relative attraction of the urban area, etc.) to leave their environment of origin.

The survey on which this research is based was carried out on six institutions, three secondary schools defined as urban and three so-called rural secondary schools. Troisième students were interviewed through a twenty-two question questionnaire. There were 315 returned questionnaires divided into two subgroups, 146 rural and 169 urban students. The next section will therefore be based on girls from both territories to find out the differences and similarities between these two groups. This sub-base consists of 164 girls, 94 of whom are from urban areas and 70 from rural areas.

Students were asked about their career orientation wishes after the class of Troisième. If we crossanalyze with the gender factor, we obtain results that seem to give a first explanation.

\begin{tabular}{|c|c|c|c|c|c|c|c|}
\hline $\begin{array}{c}\text { GNEDER } \\
\text { M/F/diploma } \\
\text { after sec. } \\
\text { school }\end{array}$ & $\begin{array}{c}\text { Non- } \\
\text { response }\end{array}$ & CAP & $\begin{array}{c}\text { Professional } \\
\text { Baccalaureate }\end{array}$ & $\begin{array}{c}\text { General } \\
\text { Baccalaureate }\end{array}$ & $\begin{array}{c}\text { Technological } \\
\text { Baccalaureate }\end{array}$ & $\begin{array}{c}\text { Others (to } \\
\text { specify) }\end{array}$ & Total \\
\hline Girls & $0.0 \%$ & $6.1 \%$ & $23.8 \%$ & $61.6 \%$ & $7.9 \%$ & $0.6 \%$ & $100 \%$ \\
\hline Boys & $2.0 \%$ & $6.6 \%$ & $25.2 \%$ & $56.3 \%$ & $8.6 \%$ & $1.3 \%$ & $100 \%$ \\
\hline Total & $1.0 \%$ & $6.4 \%$ & $24.4 \%$ & $59.1 \%$ & $8.3 \%$ & $1.0 \%$ & $100 \%$ \\
\hline
\end{tabular}

Table E3.1. Crossanalysis of gender and diploma after secondary school (source: author, 315 students database 2012)

Thus, girls opt more for general and technological Seconde (tenth grade or form five) than boys: $61.6 \%$ of them want to move to general education against $56.3 \%$ of boys. More importantly, girls from rural areas represent $53.7 \%$ of students wishing to opt for general and technological Seconde against $46.2 \%$ of boys (Table E3.2). Moreover, we note very little difference between career orientations at the national level and the orientations in the sample or sub-base "rural areas," which enhances the idea of a more modest careers orientation for boys living in rural areas. 


\begin{tabular}{|c|c|c|c|}
\hline \multicolumn{1}{c|}{} & Girls & Boys & Total \\
\hline France* & $54.3 \%$ & $45.7 \%$ & $100 \%$ \\
\hline My sample & $53.8 \%$ & $46.2 \%$ & $100 \%$ \\
\hline Rural areas of my sample & $53.7 \%$ & $46.3 \%$ & $100 \%$ \\
\hline
\end{tabular}

Tableau E3.2. Percentage of students choosing General Second ('source: Ministry of National Education 2011)

This is why it seems more appropriate to compare not the gendered choices of students in the entire sample, nor the gendered choices of students from rural then urban areas, but the choices of girls from rural and urban areas, in order to try to appreciate the significance of the territory on girls' career orientation.

By comparing students from both territories through the entire questionnaire, we find that there are differences between students that are sometimes statistically significant, especially when we compare their career orientation. This is not surprising because, as previous OER research has shown, the significance of the place of residence is a variable to consider when it comes to career orientation. Girls opt more globally for general and technological education, and on this study girls wish more than boys to aim at these same fields. But what about girls from rural areas? What is the significance of the territory on their career orientation? Does it have a positive or negative impact? Is it a repulsive factor that helps and makes you want to "escape"? Or does another territory attract them?

\section{E3.4. Career orientation wishes of girl students}

It can be seen from Table E3.3, which crossanalyses girls' career orientations with place of residence, that many more girls from rural areas opt for the CAP representing $8.6 \%$ while girls from urban areas have 3.3 percentage points lower at $5.3 \%$. Repeating is, so to speak, identical between the two areas. In effect, it concerns $1.4 \%$ and $2.1 \%$ of girl students, that is $1.8 \%$ in total. Then, in vocational Seconde class, we find more than a quarter of girl students from the urban area representing $26.6 \%$ while girls from rural areas are $12.9 \%$. Which is about half as much for rural students.

\begin{tabular}{|c|c|c|c|c|c|}
\hline $\begin{array}{c}\text { Place of } \\
\text { residence/orientation }\end{array}$ & CAP & Repeating & $\begin{array}{c}\text { Vocational } \\
\text { Seconde }\end{array}$ & $\begin{array}{c}\text { General and } \\
\text { technological } \\
\text { Seconde }\end{array}$ & Total \\
\hline Urban students & $5.3 \%$ & $2.1 \%$ & $26.6 \%$ & $66 \%$ & $100 \%$ \\
\hline Rural students & $8.6 \%$ & $1.4 \%$ & $12.9 \%$ & $77.1 \%$ & $100 \%$ \\
\hline Total & $6.7 \%$ & $1.8 \%$ & $20.7 \%$ & $70.8 \%$ & $100 \%$ \\
\hline
\end{tabular}


Table E3.3. Crossanalysis of place of residence and career orientation (source: author, girl students database 2012)

NB: dependence is significant: $\operatorname{chi} 2=10.07, \mathrm{ddl}=4,1-\mathrm{p}=96.07 \%$. The blue and pink boxes are those for which the actual number is much higher (lower) than the theoretical number.

The general and technological Seconde class is the orientation most often chosen, both in the rural and urban areas. Thus, $77.1 \%$ of girls from rural areas orient themselves to general and technological Seconde and girls from urban areas represent 66\%. There is still 11.1 points difference between the two, which is largely significant. At first sight, we could conclude that girls from rural areas choose, because of their territorial location, a more ambitious career orientation, in view of success standards and common places related to them, than their counterparts in urban territories, but we must not forget that the level and socioprofessional category of parents have a strong influence during career orientation.

Table E3.4 is built on the sole basis of girls who have not repeated. They have a score between 10 and 14, we eliminated the weakest and strongest of the group. Fathers and mothers belong to socioprofessional category 2 or 3 , in order to avoid taking either the most privileged or most disadvantaged categories.

\begin{tabular}{|c|c|c|c|c|c|}
\hline $\begin{array}{c}\text { Place of } \\
\text { residence/orientation }\end{array}$ & CAP & $\begin{array}{c}\text { Vocational } \\
\text { Seconde }\end{array}$ & $\begin{array}{c}\text { General and } \\
\text { technological } \\
\text { Seconde }\end{array}$ & Repeating & Total \\
\hline Urban & $4.6 \%$ & $22.7 \%$ & $72.7 \%$ & $0.0 \%$ & $100 \%$ \\
\hline Rural areas & $5.6 \%$ & $11.1 \%$ & $83.3 \%$ & $0.0 \%$ & $100 \%$ \\
\hline Total & $5.0 \%$ & $17.5 \%$ & $77.5 \%$ & $0.0 \%$ & $100 \%$ \\
\hline
\end{tabular}

Table E3.3. Crossanalysis of place of residence and career orientation (source: author, girl students database 2012)

With regard to Table E3.4, we can see that $5.6 \%$ of rural area girls opt for the CAP against $4.6 \%$ for urban area girls. Vocational Seconde is chosen by $22.7 \%$ of girls from the urban area against $11.1 \%$ of girls from rural areas. The general and technological Seconde, which remains the reference in terms of "good" career orientation, and which is classically chosen by the best, is the option where we find the largest gap between the two territories. Indeed, girls from rural areas are more likely to opt for this field of education, they represent $83.3 \%$, while girls from the urban area are $72.7 \%$ to move to general and technological Seconde, again, almost 11 points difference. Girls from rural areas therefore have a "better" career orientation than girls 
from urban areas at the same level, with equivalent parents' socioprofessional categories at equal age.

Then, girl students were asked the following question: "Would you like your future educational establishment to be in the same place as your secondary school? The responses were crossanalyzed with the place of residence. The majority of answers to this question is no with girls from urban areas representing $63.8 \%$ and girls from rural areas $65.7 \%$. What can be the cause of this massive rejection of their territory? Girls who answered "no" in the questionnaire were asked to explain. The answer most often given by girls from rural areas was that the "high school is not in the same area," which does not seem to be neither negative nor positive, but simply a "technical" observation. $10 \%$ of them from urban areas made this same observation. Finally, the other aspect of explanations is the emphasis on the attraction to another territory. $11.7 \%$ of girls from urban and $23.9 \%$ from rural areas give this explanation.

We can therefore note from these responses that girls from rural areas somehow massively reject their territory, which is not really the case with girls from urban areas. This may be an explanation for the desire to leave the rural area, and therefore have a career orientation that allows to "escape" from the rural world and to find work outside of it.

But do they want to live in this territory while working in another? That's why we asked the following question: "Would you like to live in the same municipality as today to work after your studies?" Girls were then asked to give their opinion with regard to different territories. A crossanalysis of the answers to this question with the place of residence, produces Table E3.5 below.

According to Table E3.5, rural area girls would not like to work in the countryside in $58.6 \%$ of cases and for $22.9 \%$ they would like to live there. In comparison, $79.8 \%$ of urban area girls responded "I would not like" to work in the countryside. We find in this response the urban-rural divide with undoubtedly a negative vision of the latter, moreover there are only $3.2 \%$ who answered "I would like" to work in the countryside. Even if girls from rural areas reject the countryside, it is knowingly because they live there, and we saw earlier that many want to change, to see something else and are aware of the lack of work in these territories, but the rejection by urban territory girls is perhaps due to assumptions. Then, the small town is discarded by $37.2 \%$ of girls from urban areas and $24.3 \%$ from rural areas. Almost a third of girls in rural areas would like to work in a small town, $32.9 \%$ against $20.2 \%$ for their urban area counterparts. The big city has a larger appeal, especially among girls from urban areas, with $75.5 \%$ responding "I would like" and $52.9 \%$ for girls from rural areas. It is rejected by $4.3 \%$ of urban area girls and $18.6 \%$ of rural area girls. So we find this rejection of the countryside and attraction of cities, or even the big city, that we saw above. Is this desire to leave reflected in the career orientation? Table E3.6 gives explanations to the 
previous question and we crossanalyzed it with the place of residence and girls who answered "no."

\begin{tabular}{|c|c|c|c|c|c|c|}
\cline { 2 - 7 } & \multicolumn{2}{c|}{ Countryside } & \multicolumn{2}{c|}{ Small town } & \multicolumn{2}{c|}{ Big city } \\
\cline { 2 - 7 } & Urban & $\begin{array}{c}\text { Rural } \\
\text { areas }\end{array}$ & Urban & Rural areas & Urban & $\begin{array}{c}\text { Rural } \\
\text { areas }\end{array}$ \\
\hline Non-response & $2.1 \%$ & $0 \%$ & $2.1 \%$ & $0 \%$ & $2.1 \%$ & $0.00 \%$ \\
\hline I would like & $3.2 \%$ & $22.9 \%$ & $20.20 \%$ & $32.90 \%$ & $75.50 \%$ & $52.90 \%$ \\
\hline Indifferent & $140 \%$ & $18.6 \%$ & $40.40 \%$ & $42.90 \%$ & $18.10 \%$ & $28.60 \%$ \\
\hline I would not like & $79.8 \%$ & $58.6 \%$ & $37.20 \%$ & $24.30 \%$ & $4.30 \%$ & $18.60 \%$ \\
\hline
\end{tabular}

Table E3.5. Appreciation of different territories (countryside, small town, big city) (source: author, girl students database 2012)

\begin{tabular}{|c|c|c|}
\hline --- & Urban & Rural \\
\hline No response & $50.0 \%$ & $23.1 \%$ \\
\hline I don't know & $3.7 \%$ & $0.0 \%$ \\
\hline $\begin{array}{c}\text { Move to a big city or another } \\
\text { location to discover something } \\
\text { else }\end{array}$ & $22.2 \%$ & $51.9 \%$ \\
\hline It's far from everything & $11.1 \%$ & $7.7 \%$ \\
\hline No jobs & $11.1 \%$ & $11.5 \%$ \\
\hline Relocation & $0.0 \%$ & $1.9 \%$ \\
\hline Never & $0.0 \%$ & $1.9 \%$ \\
\hline Not specifically & $1.9 \%$ & $0.0 \%$ \\
\hline Total & $100 \%$ & $100 \%$ \\
\hline
\end{tabular}

Table E3.6. Explanations of girls who answered "no" (source: author, girl students database 2012)

NB: dependence is significant: chi $2=30.84, \mathrm{ddl}=16,1-\mathrm{p}=98.59 \%$. The blue and pink boxes are those for which the actual number is much higher (lower) than the theoretical number.

Firstly, more than half (51.9\%) of girls from rural areas explain that they wish to "move to a big city or discover something else" against $22.2 \%$ for those who live in an urban municipality. Added to this are the answers "it's far from everything" and "no jobs" given by girls from urban areas. These responses are given in almost the 
same way for girls from rural areas with $7.7 \%$ of responses for the first and $11.5 \%$ for the second. Once again, we note differences between the two areas but especially the highlighting of the three explanation modes:

- rejection of the current territory;

- attraction of another territory;

- territory consciousness.

But, what is territory consciousness? It can be defined as follows: "Territory is to space what class consciousness is to class: something that we integrate as part of ourselves, and that we are therefore ready to defend" (Brunet, Ferras \& Thierry, 1993, p. 480). During this study, the integration of the territory could be identified in different ways. Girl students therefore have a fairly clear vision of the territory where they live. With regard to the labor market and its limitations, they take them into account. By integrating this vision, girls will therefore mobilize the opportunities offered for them to leave this territory via orientation for their future job in order to avoid through strategies to find themselves without opportunities. These three criteria were, all along, the cornerstones of the explanations given by girls in order not to live in their current territory. Certainly, with more or less intensity depending on the territory, but the fact remains that a vast majority do not wish to live in their current territory. The following question can be asked since we find almost the same behavior in both territories: is it due to the territory or simply due to age and a moment of life where rejection is a way of building up psychologically, as well as the desire to discover other territories, other spheres, while being aware of the territory surrounding us? But does everything that has been said since the beginning of this part has a real influence on career orientation?

\section{E3.5. Conclusion}

The initial hypothesis is therefore partially validated since it can be seen that girls from rural areas opt more for general and technological Seconde than girls from urban areas. They do not necessarily have the will to leave and return: though some are not against, the majority wants to leave without indicating that they wish to return.

Though rural area girls' career orientation is more significant in general and technological Seconde than that of girls from urban areas, and this has equivalent academic results and identical social background, the explanations are however multiple and complex. There are those who have a negative view of their current territory, those who have a positive vision of other territories and those who see it as having no professional future. But the girls' career orientation shows no necessary desire for escape. The latter may be a pull factor, but it does not influence girls from urban areas more than those from rural areas. 
This research work has shed new light on the influence of the territory on career orientation and, especially, to conclude that there is a specific territory effect on the rural area girls' career orientation. To continue to understand why girls from rural areas opt more for general and technological fields, individual interviews should be conducted to know their real motivation and avoid any biases that a questionnaire may have. Another possibility would be to follow such a sample over several years in order to know their vision of the territory in which they evolved, if their vision of the "dreamed" territory that is the big city could be modified. Especially for those who were educated in a large municipality, if the countryside is not appealing to them at all or if on the contrary there is a renewed attraction on the part of the latter.

Indeed, the territory effect is a cumulation over the school years which influences students in an evolving way (Champollion, 2013). Though, in primary school, it brings rural area students something more in academic results, it is however more negative for certain categories of students in terms of career orientation, especially among boys. After secondary school, the territory may certainly still influence but perhaps in a different way. It is therefore important at certain levels of schooling, but it may not be immutable in its modalities. One could thus also try to see if the "dreamed" territory has moved or dissipated. A longitudinal study would make it possible to know the type of Baccalaureate that girls from rural areas mostly obtain and, also, to know if the territory effect continues beyond secondary school. Though the territory effect on girls' career orientation has a positive effect, it nevertheless also has its potentially negative trend with academic failures related to the territory as shown by the TEDS (territories and school dropout) project advocated by Pierre-Yves Bernard "which aims at appreciating the territorial variations of school dropout in France, in order to determine the contextual effects on this phenomenon and better understand the diversity of pathways and reasons for young people's dropout" (Bernard, 2014).

It thus seems essential to understand all the different impacts of the territory or rather territories in order to be able to retain the best in each case in view of a transposition if it proves feasible to increase the chances of academic success of all students, whether boys or girls, living in urban or rural areas.

\section{E3.6. Bibliographic references}

Alpe, Y., Fauguet, J.-L., «Les idéologies du territoire : des alibis pour les politiques éducatives en milieu rural ?», Recherches en Éducation, disponible à l'adresse : http://www.recherchesen-education.net/IMG/pdf/REE-no8.pdf, 2010.

Arrighi, J.-J., «Les jeunes dans l'espace rural : une entrée précoce sur le marché du travail ou une migration probable », Formation Emploi, n 87, 2004. 
Barthes, A. \& Champollion, P. (DIR.), L'enseignement scolaire en milieu rural et montagnard, Tome $6:$ L'école rural et montagnarde en contexte nord-méditerranéen, apporches sociospatiales, Presses Universitaires de Franche-Comté, Besançon, 2014.

Baudelot, C. \& Establet, R., Allez les filles !, Le Seuil, Paris, 1992.

Bernard, P.-Y., Le projet TEDS, voir http://www.cren.univ-nantes.fr/1410351238270/0/fiche actualite/.

Boudrieu, P., Chamboredon, J.-C. \& Passeron, J.-C., La reproduction. Éléments pour une théorie du système d'enseignement, Éditions de Minuit, Paris, 1970.

Broccolichi, S., Ben-Ayed, C., Mathey-Pierre, C. \& Trancart, D., «Fragmentations territoriales et inégalités scolaires : des relations complexes entre la distribution spatiale, les conditions de scolarisation et la réussite des élèves », Éducation et formations, n ${ }^{\circ}$ 74, p. 31-48, 2007.

Brunet R., Ferras R., Théry H., Les mots de la géographie, dictionnaire critique, La Documentation française, Paris, 1993.

Champollion, P., Les inégalités d'éducation et d'orientation d'origine territoriale, L'Harmattan, Paris, 2013.

May-Carle, T., Les effets des contextes territoriaux ruraux sur les trajectoires scolaires des garçons et des filles : l'exemple du rural isolé et du rural sous faible influence urbaine, Thèse de doctorat, Universite d'Aix-Marseille, 2012. 
